\title{
The Modern Historiography of the World War II (1941-1945)
}

\author{
Natalia V. Lyapunova ${ }^{1}$, Nikolai V. Starostenkov ${ }^{1}$, Tatiana E. Demidova ${ }^{1}$, Gennady G. Provadkin ${ }^{1} \&$ Vladimir E. \\ Makarov $^{1}$ \\ ${ }^{1}$ Russian State Social University, Russia \\ Correspondence: Natalia V. Lyapunova, V. Pika 4, 1, Moscow, 129226, Russia.
}

Received: February 28, 2015 Accepted: March 20, 2015 Online Published: April 26, 2015

doi:10.5539/res.v7n6p302

URL: http://dx.doi.org/10.5539/res.v7n6p302

\begin{abstract}
The article analyzes the historiography of the last two decades of the Great Patriotic War. It is noted that they key problems of historical science have been its further expansion and the theoretical improvement of researches in the field of military history; recreation, based on the scientific analysis of objective, historically truthful picture of the causes, course and the results of the war; identification of sources and patterns of soviet's people victory in the Great Patriotic War.
\end{abstract}

Keywords: modern historiography, the Great Patriotic war in 1941-1945, historiographical analysis, historical researches

\section{Introduction}

The $70^{\text {th }}$ anniversary of the Victory in the Great Patriotic War is approaching. Along with objective researches, dedicated to the history of the struggle of soviet's people with German-Fascist invaders, Russian and European medias are full of different kinds of falsifications, which diminish the crucial role of the USSR in saving humanity from fascist enslavement and death. According to V. Putin "a half-truth is always insidious... the former tragedies, thoughtless or meaningful, would inevitably lead to the emergence of new historical and political phobias, which push states and nations together and affect the social consciousness, distorting it for the sake of dishonest politicians" (Putin, 2009). The main objective of Russian historical science is to show the patterns and sources of the Great Victory, bringing them to the citizens of our country and abroad, because during the last two decades the new generation has grown up in new historical conditions. According to the historiographical analysis, the main positive change of last decades has been the creation of preconditions for qualitative leap in the national historiography on the basis of attraction previously inaccessible archival documents and materials, the refusal of political settings, ideological veto on covering "unpleasant" scenes of the military past, the realization of the fact that the nihilism towards the past has the effect of boomerang on the most important state institutions - the army, education and culture.

\section{Methods}

The introduction of the concept of "cultural and historiographical space" to scientific circulation allows to trace the history of ideas, views on the key periods of the Great Patriotic War, as well as to demonstrate that Russian and Western historians are on the same subject field, but they operate in qualitatively different cultural and historiographical spaces. Somehow it explains the existence of significant theoretical and ideological differences between historical schools and courses towards some results of their researches and historical conceptions. Moreover, the applications of this concept in formulation of new questions to the already well-known sources helps to increment historical knowledge, evaluate and verify existing hypotheses. "Cultural and historical space" is specifically organized, logically conceivable form, which serves as the environment for an integrated subject of knowledge (historical school, individual historian and etc.), under the influence of which it formulates and operates. The most important parameters of the cultural and historical space are: the dominant ideology; social and political order; array of historiographical sources and historically established technique to interpret them; prevailing in the professional environment social and cultural traditions; the identity of the historian, which is manifested through the system of political views and historical prejudices and which could be influenced by national identity, personal preferences and social status.

\section{Results}

The analysis of the Russian and Western markets of military-historical literature has revealed two distinct 
trends of recent historiography. The first one reflects the desire of authors to coverage objectively the history of the Great Patriotic War, including the courage and heroism of the Soviet people at the front and in the rear, the decisive role of the Soviet people and its Armed Forces in the victory over the Nazi invaders and militarist Japan. The second tendency is typical for some foreign historians and publicists, as well as for some antipatriotic Russian authors, who share their views. This tendency expresses a set to deliberate distortion of historical facts and events, summarizes pseudoscientific basis, using manipulation of facts, concepts and other methods of sophistry, which justify the public revision of the results and the very meaning of the Second World War. The main objective of such falsifications is to stress the damaging for Soviet's regime propaganda and suggest anti-Russian policy guidance in the interpretation of the last year events. Characteristically, at the present stage of social contradictions between the West and Russia, the historical interpretations are given an unenviable propaganda role. Moreover, there has been an identification of the main approaches to evaluate events of the Great Patriotic War and to use the results in practice: the conservative-dogmatic approach, which rejects a balanced view on a range of military history, excluding the multivariate nature of controversial issues discussion; negative and nihilistic approach, characterized by disrespectful and sometimes dismissive attitude to the work of historians of previous generations, and finally creatively constructive approach, based on multidimensional analysis of military and historical events.

\section{Discussion}

\subsection{Basic Trends of the Development of Modern Historiography of the Great Patriotic War}

It is well known, that from the beginning of the socio-political changes in Russian society, caused by the collapse of the Soviet state in 1991, the historical science has entered a new stage of its development. One the one hand, it was characterized by the abolition of censorship, the opening of some archives and strengthening contacts with the West, to access declassified documents and materials, which could affect the reconsideration of the Soviet's history (Yezhov, 1996). The outdoor pluralism of opinions of the late 1990-s has created the scientists desire of objective and credible research and coverage of the events of the Great Patriotic War. At that time occurred a lot of publications, which were facilitating the creation of unconventional views to interpret known and unknown facts and events and the development of new systems of reasoning. The dialogue with readers about the difficult and undisclosed questions of history, initiated by academician of the USSR Academy of Sciences A. M. Samsonov in 1987 on the pages of periodicals, resulted in a series of books whose authors share their thoughts about the causes of this situation with our country in the 30-s and 40-s of the XX century (Samsonov, 1988)

On the other hand, in addition to identifying and analyzing new layers of military history, often unproven and sometimes dismissive and angrily, under the pretext of searching for "the truth" the stereotypes of the Soviet system and the war, cultivated in the western right-wing literature since "cold War", had been duplicated. (Bosworth, 2001). The pursuit of sensation in favor of political interests led and leads to many simplifications, omissions, factual errors and ultimately to the distortion of historical facts. There were a lot of proceedings, in which sounded the frank nihilism and even cynicism in the assessment of events and personalities of the war. First of all it was the "Icebreaker" and "M-Day" of V. Rasuna, writing under the pseudonym Suvorov, which were written by the author on a pre-conceived plan, using the method, based on collation of materials from a position of extreme negativism without involving archival sources. This full of malice and hatred opus to everything Russian and Soviet, which cover the events of the war in a false light, caused a huge resonance in the society, especially among the youth. It has to be noted, that some serious works of Russian scientists, which contained the rebuke of pseudoscientific fabrications of this author and other falsifiers like him, had not appeared immediately. (Suvorov, 1992)

New research climate, which was formed after the collapse of the USSR, has generated a huge amount of pseudo-literature, all kinds of speculations and unfounded judgments (Charles, 2008). On the wave of violent events of 1991 the Russian society was covered by intense political battles around the war. These actions were developing on the background of the extreme polarization of views, which was aggravated by the public disagreement on a number of issues related to the history of the Great Patriotic War. A number of researchers, who had earned on historical speculations, thoughtlessly abandoned their earlier judgments and estimates of military and historical events (Mertsalov \& Mertsalova, 1994). In turn, the followers of soviet's past heroic values blame the so-cold "auditors" in bias and opportunism (Gareyev, 1992). Y. A. Polyakov has fairly noted, “...all that was previously considered positive, was drawn to negative, the fact of the victory over fascism appeared shaded and blurred by the reflections on evils of the system, in vain the sacrifices of the people, who fought and labored under the sword of Damocles of GULAG" (Polyakov, 1994). Characteristically, such problems as the national character of the Great Patriotic War; periodization, especially its opening and final 
periods; the activities of some commanders and The Supreme Commander; restructuring of the industry for defense; creative initiatives of rear workers, the patriotism of soviet people and its historical identity-were reviewed. The inconsistency of modern approaches to the history of the Great Patriotic War was manifested in the question of the price of victory, the theory of "unjustified victims," in attempt to portray the war as a peripheral line of the Second World War.

\subsection{The Main Directions of Development of the Modern Historiography of the Great Patriotic War}

However, if you objectively look into the new period of the historiography of World War II, it becomes obvious that historical science does not stand still, even in this critical time for her. By the mid-1990s. becomes freer access of researchers to archival sources. On their base released interesting and informative works about various aspects of the war, which raise little explored problem. For example, the work of M. A. Gareev "Disambiguation pages of the war" (Gareyev, 1995). The book by N. K. Petrova is devoted to the activity of Antifascist Committee in the USSR during the war. The question of prisoners of war on both sides rises G. V. Ezhova, V. M. Malkov, A. E. Epifanov. The problem of the Lend-Lease covered in papers L. V. Pozdeeva, M. N. Suprun (Petrova, 2001). There are newer historiographical work: on the national historiography-V. M. Kulish (1996), foreign-M. I. Frolov, on the historiography of the economy of the Volga region-E. L. Khramkova. For the first time has been paid attention to the study of the historical phenomenon as a "labor army" during the Great Patriotic War, the activities of the Russian Orthodox Church during the war, religious and national politics, international relations in the USSR in 1941-1945. (Herman \& Kurochkin, 2000; Vasiliev, 2001; Buhay \& Gonov, 2004). Continuing production of military memoirs (Tulenev, 2007). Especially should pay attention to the beginning at 1989 edition of "Books of the memory, which publishes information about the dead and missing soldiers and that serve a unique source of problems for the further development of the Great Patriotic War".

At the end of the 1990 first appeared works of the regional plan for the development of the defense industry, N. P. Shuranova (the Urals), V. T. Aniskova and A. R. Khairova (on Verhnepovolzhyu), G. V. Serebryanskay (on the Volga-Vyatsk), where at the same time exploring other unexplored problem of logistics in the war-cooperative communication industries (Shuranov, 1995). Feat of workers in Kaluga and Kursk, Orenburg during war years are devoted to I. S. Pisarenko, I. G. Grishkova, A. V. Fedorova (Pisarenko, 1998). New production problems on the rear sounded in the writings of the Leningrad defense, published A. R. Dzeniskevich (1998). Book was published by M. M. Ibragimov, G. H. Azashikova about the North Caucasus during the war (Ibragimov, 1997). Condition of agriculture, the role of the village during the war are reflected in the writings of V. T. Aniskova (1998). Development of transport and road network in the front-line and base areas of logistics, the use in the construction of the prisoners of the GUlAg (Main Directorate of Stalin's camps) is revealed in the pages of the book Y. L. Dyakova (1997). Contribution of Russian intellectuals, Soviet scientists, engineers and technicians to the victory in a new and thoroughly described in the books of N. I. Kondakova and V. N. Main, G. A .Shirokov (Kondakova \& Ma'in, 1995). Public consciousness during the Great Patriotic War, the work is addressed to N. D. Kozlov (1995). Social policy of the war years are devoted to M. S. Zinich, N. P. Paletzkiana, and N. V. Lyapunov N. V. Starostenkova and their colleagues (Zinich, 1994).

\subsection{Extension Issues of Military History}

Special subject of scientific analysis in modern historical development became acute problems such as the collaboration, Hitler's occupation policy in the Soviet Union (Semiryaga, 2000; Singleton, 1965; Clarke, 1994). It should be emphasized that the term "collaboration", which is used to refer to people who cooperated in various ways with the Nazi occupation regime, began to be used in Russia only in the post-Soviet era. In Soviet historiography science usually use the word "traitor", "accomplice". However, in the West people who collaborated with the Nazis in the Soviet Union, it is usually called them collaborators. Failure of modern Russian historiography from outdated ideological installations and attracting new factual material allowed, according to E. F. Krinko, to form a clearer picture of the nature and size of the phenomenon, identify its causes and motives. These include various circumstances objective and subjective: dissatisfaction Soviet regime, mass repression, collectivisation, national and religious policy, the plight of prisoners of war and the inhabitants of the occupied areas, and their desire to survive, personal aspirations of individuals (Krinko, 2009).

Currently, the first steps in the study of the Institute of evading military service and deserters. It should be stressed that this issue only in one way or another, affects in a number of papers on various aspects of the Great Patriotic War. Characteristically, that their authors did not consider the underlying causes of evasion and desertion, but merely put forward the version that the roots of these shameful events were in class hatred dodgers and deserters to the Soviet government, and the national intolerance traitors to the Russian representatives and other nationalities. (Polyan, 2001). Based on documentary materials, G. G. Ibatullin shows the tragic fate of the 
people, who by force of circumstances become traitors to the motherland. Characteristically, many criminal elements, deliberately trapped outside the ranks of the Red Army deliberately siding with the enemy. Assessing defected to the Nazis and formed the backbone of the Vlasov Army, as well as a number of Cossack units of the Wehrmacht traitors, AV Hams and AA Platonov indicate their criminal activities: participation in the cartel operations, the extermination of the civilian population. The total number of traitors, including draft dodgers and deserters, as calculated by A. S. Barsenkov and A. I. Vdovin, $1.5 \mathrm{mln}$. People (Ibatullin, 1999).

The Soviet official science for obvious ideological reasons many years silenced about participation of the Cossacks in the Great Patriotic War. With the advent of glasnost, the topic has become very popular in the scientific community. There are works, covering the history of development and combat activities of Cossack organizations and groups, as in the Red Army, and in the ranks of the German armed forces. Among the studies on the Cossack collaborationism most prominently takes monograph P. Krikunova. In a study by D. D. Penkovsky great attention is paid to the functioning of White emigre Cossack organizations in the territory in both Europe and Asia, showing the political and military implications of intervention policy in their affairs authorities in Germany and Japan for use in the anti-Soviet policy of the Cossacks (Voskoboynikov, 2006). Currently existing historiographical emphasis in the study of "Soviet-patriotic or" collaborationist "theme leads to some of its dissociation, does not give a whole historical picture. For this reason, it would be appropriate to create general work, which would be covered all aspects of the participation of the Cossacks in the Great Patriotic War.

\subsection{Studied Topics in the History of the Great Patriotic War}

Korneev, V. V. (2011) dedicated his work to the analysis of the historiographical literature, which considers the peculiarities of the far East region's functioning during the great Patriotic war, occupying a special place among the rear areas of the USSR. The author notes that from the point of view of traditional research topics in modern Russian historiography became general works, in which considers some aspects of the far East population, the infrastructure's condition and industry in the region during the war. The extension of the source base, which previously was not available to historians, enabled them to analyze in detail various aspects of the economy, the defense potential of the region, as well as features of social consciousness of the inhabitants of the region. Discussion in the recent historiography of the questions on allied relations of the USSR with the countries of anti-Hitler coalition, and, above all the problems of lend-lease supplying. Well known, in domestic and foreign historiography the Northern convoys was traditionally considered the main supply route. However, Presented by V. P. Puzyrev, E. Sugareva and A. V. Bass statistic data testify the leading role of the far Eastern way of transportation of goods under lend-leas (Puzyrev et al., 1995). A. H. Paperno comes to the same conclusion in his popular science book. Based on data from various domestic and foreign sources, the historian has made a conclusion, that the total cargo's volume lend-lease delivered by sea to the Soviet far East $(49.7 \%$ of all cargo lend-lease) was significantly higher than the corresponding supply in the USSR during the famous Northern convoys (Paperno, 2007). In a series of specialized historical research should highlight works that discuss the features of the production activity of Dalstroy the USSR, in a region different "special forces", as well as issues related to religious situation in the far East 1941-1945 (Batsaev, 2002). In general, it is impossible not to mention that, despite the availability military archives, a lot of the key problems of the war still have not received proper lighting. We should include a question about combat losses on the Soviet-German front, and the tragedy of Soviet prisoners of war, health consequences of war, demographics, and government is not enough published works about the fate of certain country's regions during the war. Not uncommon substitution assess and value the lessons of the great Patriotic war the outcome of the Second world war, the heroism of the soldiers at the front is contrasted with the heroism of the workers in the rear.

\section{Conclusion}

As can be seen, for the period from the early 1990s to the present time in the Russian market historical literature has a huge number of works on the history of the great Patriotic war, which is partially echoed in the historiographical works. But historiographers have yet to give a detailed and objective assessment of these works (Liu et al., 2012; Waldenström et al., 2008). Today there is a rethinking of the Great Patriotic War, in accordance with the new socio-political realities, the most important aspect of which is its methodological re-based integrated paradigm of historical analysis, the formation of new cultural and historiographical space created new possibilities for the formation of different views on the past, including the history of the Great Patriotic War. Expanding the sources database research, created more favorable conditions for its accessibility to a wide range of specialists. More and more attention is paid to the previously unknown events of military-historical past, the most controversial issues. From all this it can be concluded that further study of contemporary historiography of World War II continues to be an urgent task of the Russian historical science. 
As you can note the following conclusions:

Firstly, a large historiographical analysis of the literature on the Great Patriotic War, published in the post-Soviet period, showed that its problems, the range of the issues involved, thanks to the liberalization of all public life in the country, pluralism and expanded information base by attracting previously closed materials increased significantly.

Secondly, an important place in the development trend of research on the Great Patriotic War continues to occupy the desire of the authors to show the objective of its history.

Third, in the period under review has become a growing trend, characteristic of foreign historians and publicists, as well as share their views of the antipatriotic minded Russian authors. It expresses the focus on total falsification of the Great Patriotic War, as part of the Second World War, and the justification of the review of its results conformable to the new outlook of the West.

In conclusion, to thank all my colleagues, with the assistance of which was carried out a study of contemporary historiography of the Great Patriotic War. The article was prepared within the project "Research groups scientific and educational centers in the field of historical sciences" of the Ministry of education and science of the Russian Federation on the topic "Methodology and basic concepts of modern domestic historiography of the great Patriotic war (1991-2011ss.).

\section{References}

Aniskov, V. T. (1998). The war and the fate of the Russian peasantry. Vologda: Yaroslavl.

Batsaev, I. D. (2002). Features of the industrial development of the North-East of Russia in the period of mass political repressions (1932-1953). Dalstroy: Magadan.

Bosworth, R. J. B. (2001). Second World War. In N. J. Smelser, \& P. B. Baltes (Eds.), The International Encyclopedia of the Social \& Behavioral Sciences (pp. 13771-13777). Pergamon: Oxford.

Buhay, N. F., \& Gonov, A. M. (2004). North Caucasus: new directions of national policy (90-ies of XX century). M.

Clarke, I. F. (April 1994). World War II, or, what did the future hold? Futures, 26(3), 335-344.

Dyakov, Y. L. (1997). Development of transport and the road network of the USSR in 1941-1945. M.

Dzeniskevich, A. R. (1998). Front from the factory walls. In Raises the problem of the defense of Leningrad (1941-1944). Spb.

Gareyev, M. A. (1992). On the study of the history of the Great Patriotic War. Modern and Contemporary History, 1, 3-24.

Gareyev, M. A. (1995). Ambiguous page War: Essays on the problematic issues of the Great Patriotic War. M.

Herman, A. A., \& Kurochkin, A. N. (2000). The Germans in the USSR "labor armii (1941-1945ss) (2nd ed.). M.

Ibatullin, G. G. (1999). The war and captivity. SPb.

Ibragimov, M. M. (1997). The peoples of the North Caucasus in the Great Patriotic War of 1941-1945. M.

Kondakova, N. I., \& Ma'in, V. N. (1995). Russian Intelligentsia, 1941-1945. M.

Korneev, V. V. (2011). Far East of the USSR in the Great Patriotic War in the modern Russian historiography (1991-2010). Problems of the Far East, 3, 117-122.

Kozlov, N. D. (1995). Public consciousness of the Great Patriotic War (1941-1945). Spb.

Krinko, E. F. (2009). Modern Russian historiography of World War II: The results of two decades. Past Years, 4(14), 6-21.

Kulish, V. M. (1996). Soviet historiography of the Great Patriotic War. M.

Liu, J. H., Allen, M. W., \& Páez, D. (2012). In V. S. Ramachandran (Ed.), War, In Encyclopedia of Human Behavior (2nd ed., pp. 683-689). San Diego: Academic Press.

Mertsalov, A. N., \& Mertsalova, L. A. (1994). Stalinism and war. Of the unread pages of history (1930-1990's). M.

Paperno, A. H. (2007). The third period of glory of Petropavlovsk-Kamchatsky: The role of Lend-Lease in the city's history, the role of the city in the Pacific transport epic and some others remain unknown facts of World War II. Petropavlovsk-Kamchatsky. 
Petrova, N. (2001). Antifascist Committee in the USSR. M.

Pisarenko, I. S. (1998). The rear of the Kaluga region in the Great Patriotic War. Kaluga.

Polyakov, Y. (1994). Why have we won? On the popular consciousness during the war. Free Thought, 11.

Polyan, P. (2001). Not on their own ... History and geography of forced migrations in the USSR. M.

Putin, V. V. (2009, August 31). Shadows of the past can no longer overshadow today, and even more so tomorrow cooperation between Russia and Poland: Article for the Polish newspaper "Newspaper Wyborcza”. TVNZ.

Puzyrev, V. P., Skugarev, V. D., \& Basov, A. V. (1995). Under the flag of Russia: The origins and development of the Navy. M.

Samsonov, A. M. (1988). Know and remember: Dialogue historian with the reader. M.

Semiryaga, M. I. (2000). Collaboration. Nature, typology and the manifestation of the Second World War. M.

Shuranov, N. P. (1995). Kuzbass-the front. Kemerovo.

Singleton, F. B. (1965). Chapter iv-Eastern Europe during the second World War. In F. B. Singleton (Ed.), In The Commonwealth and International Library: Liberal Studies Division (pp. 85-109). Pergamon, Background to Eastern Europe.

Suvorov, V. (1992). Icebreaker. M.

Thomas, C. S. (2008). In K. Lester (Ed.), World War II, In Encyclopedia of Violence, Peace, \& Conflict (2nd ed., pp. 2512-2524). Oxford: Academic Press.

Tulenev, I. (2007). After three wars. In Commander of the Southern Memories and the Transcaucasian Front, 1941-1945. M.

Vasiliev, O. (2001). Russian Orthodox Church in the policy of the Soviet state in the 1943-1948. M.

Voskoboynikov, G. L. (2006). Cossacks and cavalry during the Great Patriotic War of 1941-1945. Rostov-D.

Waldenström, D., \& Frey, B. S. (2008, April). Did nordic countries recognize the gathering storm of World War II? Evidence from the bond markets, Explorations in Economic History, 45(2), 107-126.

Yezhov, V. A. (1996). 50 Years of Victory: The state of the national historiography. Problems historiography: Proceedings of the International Conference. Spb.

Zinich, M. S. (1994). Weekdays war years, 1941-1945 (Vol. 1-2). M.

\section{Copyrights}

Copyright for this article is retained by the author(s), with first publication rights granted to the journal.

This is an open-access article distributed under the terms and conditions of the Creative Commons Attribution license (http://creativecommons.org/licenses/by/3.0/). 